\title{
Diagnostic imaging of dopamine receptors in pituitary adenomas
}

\author{
Wouter W de Herder, Ambroos E M Reijs ${ }^{1}$, Richard A Feelders, Maarten O van Aken, Eric P Krenning ${ }^{1}$, \\ Aart-Jan van der Lely and Dik J Kwekkeboom ${ }^{1}$ \\ Departments of Internal Medicine and Nuclear Medicine ${ }^{1}$, Erasmus MC, Rotterdam, The Netherlands \\ (Correspondence should be addressed to $W W$ de Herder who is now at the Sector of Endocrinology, Department of Internal Medicine, Erasmus MC, \\ S-Gravendijkwal 230, 3015 CE Rotterdam, The Netherlands; Email: w.w.deherder@erasmusmc.nl)
}

\begin{abstract}
Dopamine D2 receptor scintigraphy of pituitary adenomas is feasible by single-photon emission computed tomography using ${ }^{123} \mathrm{I}-\mathrm{S}-(-)-\mathrm{N}$-[(1-ethyl-2-pyrrolidinyl)methyl]-2-hydroxy-3-iodo-6methoxybenzamide $\left({ }^{123} \mathrm{I}-\mathrm{IBZM}\right)$ and ${ }^{123}$ I-epidepride. ${ }^{123}$ I-epidepride is generally superior to ${ }^{123}$ I-IBZM for the visualization of D2 receptors on pituitary macroadenomas. However, ${ }^{123}$ I-IBZM and ${ }^{123}$ I-epidepride scintigraphy are generally not useful to predict the response to dopaminergic treatment in pituitary tumour patients. These techniques might allow discrimination of non-functioning pituitary macroadenomas from other non-tumour pathologies in the sellar region. Dopamine D2 receptors on pituitary tumours can also be studied using positron emission tomography with ${ }^{11} \mathrm{C}$-N-raclopride and ${ }^{11} \mathrm{C}-\mathrm{N}$-methylspiperone.
\end{abstract}

European Journal of Endocrinology 156 S53-S56

\section{Introduction}

Pituitary adenomas are subclassified according to hormonal hypersecretion into clinically functioning and clinically non-functioning. Among the hormone products secreted are: prolactin (PRL), growth hormone (GH), adrenocorticotrophic hormone (ACTH), thyroid-stimulating hormone (TSH), gonadotrophins (luteinizing hormone and follicle-stimulating hormone) or glycoprotein hormone subunits.

In the field of nuclear medicine, positron emission tomography (PET) and single-photon emission computed tomography (SPECT) techniques have become available for the study of dopamine D2 and D3 receptors and somatostatin receptor subtype expression. For a review on the latter, see reference (1).

\section{Dopamine D2 receptors}

The expression of functionally active dopamine D2 receptors has been demonstrated in PRL-, GH-, ACTH-, TSH-secreting and clinically non-functioning pituitary tumours (2-11). The presence of high numbers of high-

This paper was presented at a symposium held at the Erasmus Medical Center, Rotterdam, The Netherlands, 2005. The symposium was jointly organized by LJ Hofland, Erasmus Medical Center, and A Colao, Federico II University of Naples, Italy. Ipsen partially supported the publication of these proceedings. affinity D2 receptors on prolactinomas, some GH-, TSHand ACTH-secreting tumours is the pharmacological basis for therapy with dopamine receptor agonist drugs, like the ergot-derived substances bromocriptine, pergolide and cabergoline and the nonergot dopamine agonist quinagolide (7).

\section{Dopamine D2 receptor SPECT}

Several centres, including our own, have shown that D2 receptor scintigraphy of pituitary adenomas is feasible by SPECT using ${ }^{123} \mathrm{I}-\mathrm{S}-(-)-\mathrm{N}$-[(1-ethyl-2-pyrrolidinyl)methyl]-2-hydroxy-3-iodo-6-methoxybenzamide $\left({ }^{123} \mathrm{I}\right.$ IBZM; 12-15). In a patient with a metastatic malignant macroprolactinoma, ${ }^{123}$ I-IBZM SPECT failed to visualize the primary tumour, whereas the uptake in a metastasis was lower than that observed for the striatum. A partial response of this metastatic tumour to quinagolide could be demonstrated in vivo and in vitro (16). In another patient with a mixed TSH/ $\alpha$-SU/PRL-secreting pituitary macroadenoma, SPECT with ${ }^{123}$ I-IBZM and ${ }^{111}$ InDTPA-pentetreotide both visualized the tumour (17). An acute in vivo response of the tumour to octreotide and bromocriptine could be demonstrated. However, long-term combined treatment did not result in tumour regression or a decrease in circulating hormone levels (17). Thus, the demonstration of receptors in vivo in these patients did not positively predict the outcome of medical therapy with these two receptor agonists. 
We have performed scintigraphy using ${ }^{123}$ I-IBZM in a series of 37 patients with pituitary tumours ( 5 patients with PRL-secreting macroadenomas, 2 patients with PRL-secreting microadenomas, 17 patients with clinically non-functioning pituitary adenomas (NFPAs), 12 patients with $\mathrm{GH}$-secreting adenomas and 1 patient with a TSH-secreting macroadenoma; (15)). SPECT showed significant uptake of ${ }^{123}$ I-IBZM in the pituitary region in three out of five macroprolactinoma patients. These results correlated closely with the response of plasma PRL levels to quinagolide. In two scan-positive prolactinoma patients, repeated SPECTs during therapy with quinagolide showed a reduction in the pituitary uptake of ${ }^{123}$ I-IBZM. Pituitary SPECT was negative in the two microprolactinoma patients who responded to quinagolide administration. In 4 out of 17 patients with NFPA, significant uptake of the radioligand in the pituitary region was observed. In two out of three scan-positive NFPA patients, who were treated with quinagolide, shrinkage of the pituitary tumours was observed. Treatment with quinagolide resulted in stabilization of tumour growth in the other scanpositive patients. Four out of seventeen patients with NFPA and a negative SPECT were treated with quinagolide. Tumour growth was observed in one patient and tumour size did not change in the other three patients. The pituitary region of none of the 12 acromegaly patients showed significant uptake of ${ }^{123}$ I-IBZM (15).

Panza and co-workers have performed pituitary scintigraphy with ${ }^{123}$ I-IBZM in two patients with mixed GH/PRL-secreting pituitary tumours and acromegaly (18). One patient showed high pituitary uptake of ${ }^{123}$ I-IBZM and $>80 \%$ GH suppression was observed after a single dose of bromocriptine. Combined therapy with bromocriptine and octreotide also resulted in significant tumour regression. Another patient had negative ${ }^{123}$ I-IBZM scintigraphy and in this patient, there was no GH response to a single bromocriptine dose. In this patient, combined octreotide and bromocriptine therapy also resulted in tumour regression (18).

Ferone and co-workers have performed pituitary scintigraphy with ${ }^{123}$ I-IBZM in four patients with mixed GH/PRL-secreting pituitary tumours and acromegaly (19). One patient showed high pituitary uptake of ${ }^{123} \mathrm{I}-$ IBZM. In this patient, cabergoline therapy failed to normalize pathologically elevated GH levels. Another patient only showed slight pituitary uptake of ${ }^{123}$ I-IBZM. In this patient quinagolide reduced, but did not normalize, pathologically elevated GH levels. In two other patients, ${ }^{123}$ I-IBZM scintigraphy was negative and neither cabergoline nor quinagolide therapy was effective (19).

These studies demonstrate that the sensitivity of ${ }^{123} \mathrm{I}-$ IBZM SPECT for imaging pituitary adenomas is rather poor, which presumably results from the relatively low target:background ratio of ${ }^{123} \mathrm{I}$-IBZM binding (12-15).

These studies also show that the clinical usefulness of ${ }^{123}$ I-IBZM scintigraphy for predicting the clinical efficacy of dopamine agonists in patients with NFPAs or acromegaly is limited.

Consequently, investigators have been actively testing SPECT radiopharmaceuticals for the D2 receptor which show higher receptor affinity. Another substituted benzamide derivative, epidepride, ${ }^{123} \mathrm{I}-(\mathrm{S})-\mathrm{N}-[(1-\mathrm{ethyl}-2-$ pyrrolidinyl) methyl]-5-iodo-2, 3-dimethoxybenzamide ${ }^{123}$ I-epidepride) has shown to provide high targetto-background uptake and hence high image quality (20-22). Subsequent D2 receptor scintigraphic studies were performed using ${ }^{123}$ I-epidepride $(20,21)$. Pirker and co-workers have reported a high sensitivity of ${ }^{123} \mathrm{I}-$ epidepride SPECT for demonstrating dopamine receptors on pituitary tumours (23). We have compared pituitary SPECT after ${ }^{123}$ I-epidepride and ${ }^{123} \mathrm{I}$-IBZM in NFPAs in the same 15 patients. Four dopamine agonist-sensitive macroprolactinomas were used as positive controls (24). In parallel with studies demonstrating a much greater relative striatal uptake of ${ }^{123} \mathrm{I}$-epidepride than of ${ }^{123} \mathrm{I}$-IBZM (25), we have also observed a much higher uptake of ${ }^{123} \mathrm{I}-$ epidepride in NFPAs and macroprolactinomas than of ${ }^{123}$ I-IBZM (24). All four macroprolactinomas showed pituitary uptake of ${ }^{123}$ I-epidepride, but pituitary uptake of ${ }^{123}$ I-IBZM was only demonstrated in one of these tumours (24). The pituitary region of 9 out of 15 NFPA patients showed significant uptake of ${ }^{123}$ I-epidepride, but the uptake of ${ }^{123}$ I-IBZM was only shown in 6 out of 15 patients (24). Therefore, we concluded that ${ }^{123}$ I-epidepride is superior to ${ }^{123} \mathrm{I}$-IBZM for the visualization of D2 receptors on pituitary macroadenomas, and that therefore ${ }^{123}$ I-epidepride should be the radioligand of choice for D2 receptor SPECT studies in pituitary tumour patients (24).

We have subsequently studied the correlation between the results of ${ }^{123}$ I-epidepride scintigraphy and the radiological response to dopamine agonists in 18 NFPAs (26). Patients were treated with either cabergoline (1-2 mg/week) or quinagolide (150-300 $\mu \mathrm{g} /$ day) for a mean period of 89.7 months (range: 34-187 months). Pituitary uptake of ${ }^{123}$ I-epidepride varied from slight uptake, classified as grade 0 , to very high, classified as grade 3. Grade 0 uptake was found in four patients; grade 1 in three patients; grade 2 in ten patients and grade 3 uptake in one patient. NFPA stabilization or shrinkage with dopamine agonist therapy showed no significant difference between grades 0,1 and 2 tumours (mean tumour stabilization or shrinkage: 31,30 and $36 \%$ respectively) (26). We concluded that ${ }^{123}$ I-epidepride scintigraphy is not useful to predict the response to long-term dopaminergic treatment in NFPA patients (26). However, when we considered a decrease in tumour size ranging from 0 to $20 \%$ as tumour stabilization and $>20 \%$ decrease in tumour size as true shrinkage, one out of four NFPAs with grade 1 uptake, two out of three NFPAs with grade 1 uptake and eight out of ten NFPAs with grade 2 uptake showed tumour shrinkage (26).

As with ${ }^{123}$ I-IBZM scintigraphy, the clinical usefulness of ${ }^{123}$ I-epidepride scintigraphy for predicting the clinical 


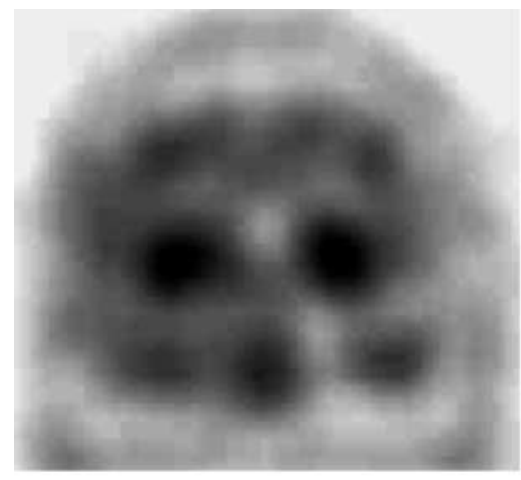

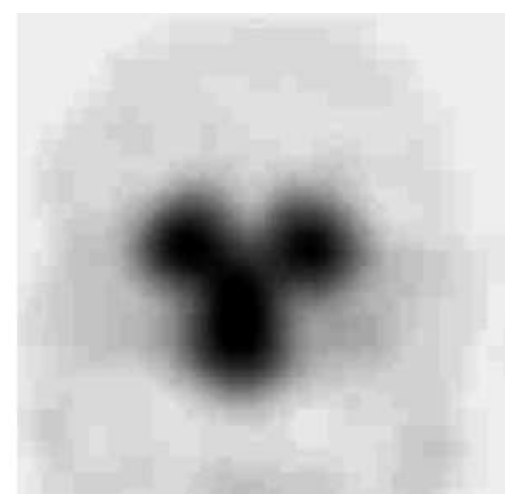

Figure 1 Preoperative ${ }^{123}$-IBZM coronal SPECT (left) and ${ }^{123}$-epidepride coronal SPECT (right) images of the head of a 64-year-old man with a clinically non-functioning pituitary macroadenoma, showing intense (grade 3 ) uptake of the radioligand in the pituitary tumour. efficacy of dopamine agonists in selected patients with NFPAs is therefore limited.

Discrimination of NFPAs from other pathologies in the sellar region is generally not difficult when modern MRI protocols are applied. ${ }^{123}$ I-epidepride scintigraphy, however, might still be useful in specific situations - for discrimination of scar tissue from NFPA recurrence or residual NFPA, or for the differential diagnosis between pituitary tumours and metastases (Fig. 1) for example.

\section{PET}

Muhr and co-workers and Bergström and co-workers have performed PET studies with ${ }^{11} \mathrm{C}$-labelled dopamine D2 antagonists such as ${ }^{11} \mathrm{C}-\mathrm{N}$-raclopride and ${ }^{11} \mathrm{C}-\mathrm{N}$ methylspiperone for in vivo measurement of $\mathrm{D} 2$ receptors in prolactinomas and GH-secreting pituitary adenomas (27-30). They have demonstrated higher dopamine receptor binding in patients responsive to dopamine agonists than in therapy-resistant patients (27-30). In a patient with a malignant prolactinoma, presenting with multiple intracranial metastases, these techniques clearly visualized the primary tumour as well as a number of metastases. Bromocriptine treatment resulted in tumour regression, a decrease in circulating PRL levels and a decrease in ${ }^{11} \mathrm{C}-\mathrm{N}$-labelled dopamine antagonist binding as determined in vivo by PET (31).

\section{References}

1 de Herder WW, Kwekkeboom DJ, Feelders RA, van Aken MO, Lamberts SWJ, van der Lely AJ \& Krenning EP. Somatostatin receptor imaging for neuroendocrine tumors. Pituitary 20069 243-248.

2 Pivonello R, Matrone C, Filippella M, Cavallo LM, Di Somma C, Cappabianca P, Colao A, Annunziato L \& Lombardi G. Dopamine receptor expression and function in clinically nonfunctioning pituitary tumors: comparison with the effectiveness of cabergoline treatment. Journal of Clinical Endocrinology and Metabolism 2004 89 1674-1683.

3 Pivonello R, Ferone D, de Herder WW, Kros JM, De Caro ML, Arvigo M, Annunziato L, Lombardi G, Colao A, Hofland LJ \&
Lamberts SW. Dopamine receptor expression and function in corticotroph pituitary tumors. Journal of Clinical Endocrinology and Metabolism 200489 2452-2462.

4 Spada A, Nicosia S, Cortelazzi L, Pezzo G, Bassetti M, Sartorio A \& Giannattasio G. In vitro studies on prolactin release and adenylate cyclase activity in human prolactin-secreting pituitary adenomas. Different sensitivity of macro- and microadenomas to dopamine and vasoactive intestinal polypeptide. Journal of Clinical Endocrinology and Metabolism 198356 1-10.

5 De Camilli P, Macconi D \& Spada A. Dopamine inhibits adenylate cyclase in human prolactin-secreting pituitary adenomas. Nature $1979278252-254$.

6 Bression D, Brandi AM, Martres MP, Nousbaum A, Cesselin F, Racadot J \& Peillon F. Dopaminergic receptors in human prolactinsecreting adenomas: a quantitative study. Journal of Clinical Endocrinology and Metabolism 198051 1037-1044.

7 Bevan JS, Webster J, Burke CW \& Scanlon MF. Dopamine agonists and pituitary tumor shrinkage. Endocrine Reviews 199213 220-240.

8 Bevan JS \& Burke CW. Non-functioning pituitary adenomas do not regress during bromocriptine therapy but possess membranebound dopamine receptors which bind bromocriptine. Clinical Endocrinology 198625 561-572.

9 Koga M, Nakao H, Arao M, Sato B, Noma K, Morimoto Y, Kishimoto S, Mori S \& Uozumi T. Demonstration of specific dopamine receptors on human pituitary adenomas. Acta Endocrinologica $1987114595-602$.

10 Serri O, Marchisio AM, Collu R, Hardy J \& Somma M. Dopaminergic binding sites in human pituitary adenomas other than prolactinomas. Hormone Research 198419 97-102.

11 Cronin MJ, Cheung CY, Wilson CB, Jaffe RB \& Weiner RI. $\left[{ }^{3} \mathrm{H}\right]$ Spiperone binding to human anterior pituitaries and pituitary adenomas secreting prolactin, growth hormone, and adrenocorticotropic hormone. Journal of Clinical Endocrinology and Metabolism $198050387-391$.

12 Pirker W, Brucke T, Riedl M, Clodi M, Luger A, Asenbaum S, Podreka I \& Deecke L. Iodine-123-IBZM-SPECT: studies in 15 patients with pituitary tumors. Journal of Neural Transmission. General Section 199497 235-244.

13 Scillitani A, Dicembrino F, Di Fazio P, Vettori PP, D’Angelo V, Scarabino T \& Liuzzi A. In vivo visualization of pituitary dopaminergic receptors by iodine-123 methoxybenzamide (IBZM) correlates with sensitivity to dopamine agonists in two patients with macroprolactinomas. Journal of Clinical Endocrinology and Metabolism $1995 \mathbf{8 0}$ 2523-2525.

14 Ferone D, Lastoria S, Colao A, Varrella P, Cerbone G, Acampa W, Merola B, Salvatore M \& Lombardi G. Correlation of scintigraphic results using ${ }^{123}$ I-methoxybenzamide with hormone levels and tumor size response to quinagolide in patients with pituitary adenomas. Journal of Clinical Endocrinology and Metabolism 1998 $83248-252$. 
15 de Herder WW, Reijs AE, Kwekkeboom DJ, Hofland LJ, Nobels FR, Oei HY, Krenning EP \& Lamberts SW. In vivo imaging of pituitary tumours using a radiolabelled dopamine D2 receptor radioligand. Clinical Endocrinology 199645 755-767.

16 Assies J, Verhoeff NP, Bosch DA \& Hofland LJ. Intracranial dissemination of a macroprolactinoma. Clinical Endocrinology 199338 539-546.

17 Verhoeff NP, Bemelman FJ, Wiersinga WM \& van Royen EA. Imaging of dopamine D2 and somatostatin receptors in vivo using single-photon emission tomography in a patient with a TSH/PRLproducing pituitary macroadenoma. European Journal of Nuclear Medicine 199320 555-561.

18 Panza N, Rambaldi PF, Battista C, Ambrosio G, Cascini GL, Schilliro F \& Mansi L. Receptor imaging with 111In-pentreotide and ${ }^{123}$ I-methoxybenzamide, and inhibition tests with octreotide and bromocriptine of mixed growth hormone/prolactin-secreting pituitary tumors. Biomedicine and Pharmacotherapy 199953 319-322.

19 Ferone D, Pivonello R, Lastoria S, Faggiano A, del Basso De Caro ML, Cappabianca P, Lombardi G \& Colao A. In vivo and in vitro effects of octreotide, quinagolide and cabergoline in four hyperprolactinaemic acromegalics: Correlation with somatostatin and dopamine D2 receptor scintigraphy. Clinical Endocrinology $2001 \mathbf{5 4} 469-477$.

20 Joyce JN, Janowsky A \& Neve KA. Characterization and distribution of [125I] epidepride binding to dopamine D2 receptors in basal ganglia and cortex of human brain. Journal of Pharmacology and Experimental Therapeutics 1991257 1253-1263.

21 Kessler RM, Whetsell WO, Ansari MS, Votaw JR, de Paulis T, Clanton JA, Schmidt DE, Mason NS \& Manning RG. Identification of extrastriatal dopamine D2 receptors in post mortem human brain with [ $\left.{ }^{125} \mathrm{I}\right]$ epidepride. Brain Research 1993609 237-243.

22 Ichise M \& Ballinger JR. SPECT imaging of dopamine receptors. Journal of Nuclear Medicine 199637 1591-1595.

23 Pirker W, Riedl M, Luger A, Czech T, Rossler K, Asenbaum S, Angelberger P, Kornhuber J, Deecke L, Podreka I \& Brucke T. Dopamine D2 receptor imaging in pituitary adenomas using iodine-123-epidepride and SPECT. Journal of Nuclear Medicine $1996371931-1937$.
24 de Herder WW, Reijs AEM, de Swart J, Kaandorp Y, Lamberts SWJ, Krenning EP \& Kwekkeboom DJ. Comparison of iodine-123 epidepride and iodine-123 IBZM for dopamine D2 receptor imaging in clinically non-functioning pituitary macroadenomas and macroprolactinomas. European Journal of Nuclear Medicine 199926 46-50.

25 Leslie WD, Abrams DN, Greenberg CR \& Hobson D. Comparison of iodine-123-epidepride and iodine-123-IBZM for dopamine D2 receptor imaging. Journal of Nuclear Medicine 199637 1589-1591.

26 de Herder WW, Reijs AEM, Feelders RA, van Aken MO, Krenning EP, Tanghe HL, van der Lely AJ \& Kwekkeboom DJ. Dopamine agonist therapy of clinically non-functioning pituitary macroadenomas. Is there a role for ${ }^{123}$ I-epidepride dopamine D2 receptor imaging? European Journal of Endocrinology $2006 \mathbf{1 5 5}$ $1-8$.

27 Muhr C, Bergstrom M, Lundberg PO, Bergstrom K, Hartvig P, Lundqvist H, Antoni G \& Langstrom B. Dopamine receptors in pituitary adenomas: PET visualization with ${ }^{11} \mathrm{C}-\mathrm{N}-m e t h y l s-$ piperone. Journal of Computer Assisted Tomography 198610 175-180.

28 Muhr C, Bergstrom M, Lundberg PO, Bergstrom K \& Langstrom B. In vivo measurement of dopamine receptors in pituitary adenomas using positron emission tomography. Acta Radiologica. Supplementum $1986369406-408$

29 Bergstrom M, Muhr C, Lundberg PO \& Langstrom B. PET as a tool in the clinical evaluation of pituitary adenomas. Journal of Nuclear Medicine 199132 610-615.

30 Muhr C \& Bergstrom M. Positron emission tomography applied in the study of pituitary adenomas. Journal of Endocrinological Investigation 199114 509-528.

31 Muhr C, Bergstrom M, Lundberg PO, Hartman M, Bergstrom K, Pellettieri L \& Langstrom B. Malignant prolactinoma with multiple intracranial metastases studied with positron emission tomography. Neurosurgery 198822 374-379.

Received 12 January 2007

Accepted 18 January 2007 